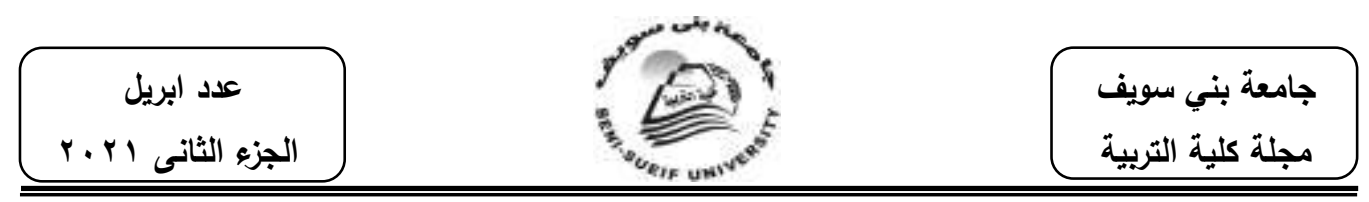

\title{
Using Project Based Learning (PBL) Program \\ Integrated with Information Technology (IT) \\ in Developing Secondary School Students' \\ Reading Skills. \\ By: Manar Abd Allah Aly
}

\section{Dr. Hayat Refaey Ali}

Professor of Curriculum\&

Methods of TEFL

Faculty of Education,

Minia University
Dr. Mukhtar Abd El Fattah Abd El Maksoud

Assistant Professor of Curriculum\&

Methods of TEFL

Faculty of Education,

Learning Program integrated with Information Technology in developing reading skills of first year secondary school students. The Participants were sixty students. They were randomly assigned to a treatment group and a control group (30 students each). The instruments of the study included a checklist of Reading sub- skills and a test on Reading skills. The treatment group was taught using Project Based Learning Program integrated with Information Technology while the control group was taught following the plan of the Ministry of Education in Egypt. The participants were pre - and - post tested. The program was administered in the first term of the academic year 2020/2021. Results revealed that Project Based Learning Program integrated with Information Technology had positive results. Recommendations and suggestions for further research were presented. Key words: project based learning, information technology and reading 
كان الهدف من هذه الدارسة هو معرفة تأثثر برنامج في التعلم القائم على المشروعات بالتكامل مع تكنولوجيا المعلومات، في تتمية مهارات القراءة لدى طلاب الصف الأول الثانوي. كان المشاركون ستون طالبا نم تقسيميهم بشكل عشوائي إلى مجموعة تجريبية

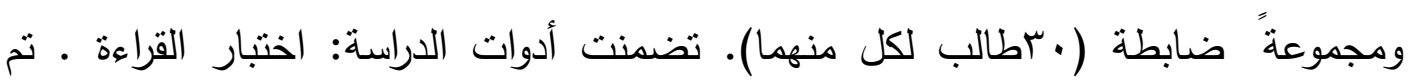
تدريس المجموعة التجريبية باستخدام برنامج في التعلم القائم على المشروعات بينما تم تدريس المجموعة الضابطة وفق لخطة وزارة التربية والتعليم في مصر ـ تم اختبار المشاركين قبل وبعد. أظهرت النتائج أن البرنامج القائم على المشروعات كان له نتائج إيجابية. وقدمت اقتراحات لمزيد من البحث. كلمات رئيسية: التعلم القائم على المشروعات،تكنولوجيا المعلومات و القراءة. 


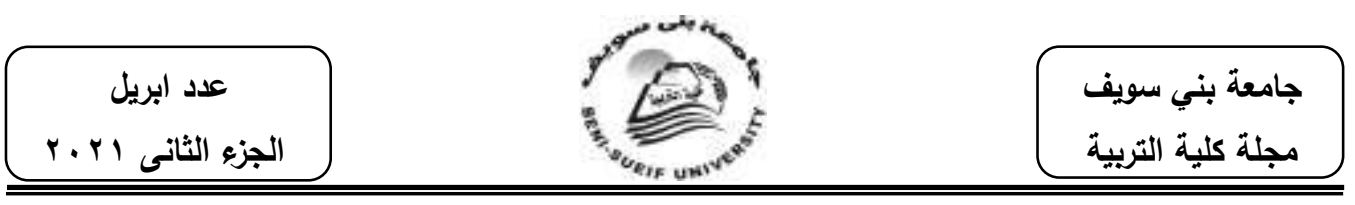

\section{Introduction}

Language has a great importance in our everyday life. We use language to inform people around us about our needs, ideas, emotions and opinions. Language is a basic means of communication through using sounds, gestures, signs or symbols. It distinguishes humans from all other living beings. Over the years, English language became the most used language all over the world. It became the international means of communication. When people from different countries want to communicate, they use English language. Knowing language is not only knowing how to understand, speak, read and write sentences but also knowing how to communicate by using those sentences (Onchera, 2013). So learners should be provided with the language system - the structures and vocabulary of English to be used for communication (Kazerooni, 2013).

Reading is a lifelong skill to be used both at school and throughout life. According to Hellyer, Robinson\& Sherwood; reading is a basic life skill. It is a cornerstone for a child's success in school and, indeed, throughout life. Without the ability to read well, opportunities for personal fulfilment and job success inevitably will be lost (2001). Despite its importance, reading is one of the most challenging areas in the education system. Reading helps strengthen language and sharpens sentence structure. All of these are critical to being a good speaker. Teachers can help improve student comprehension through instruction of reading strategies. Predicting, making connections, visualizing, inferring, questioning, and summarizing are strategies shown by research to improve reading comprehension (Block \& Israel, 2005)

reading. If the students do not have knowledge of reading skills, they cannot be

expected to be successful readers. Thus, they cannot achieve the level of

comprehension required to pass exams in their own departments. For this reason, reading skills should be taught in universities for the students to be able to cope with 


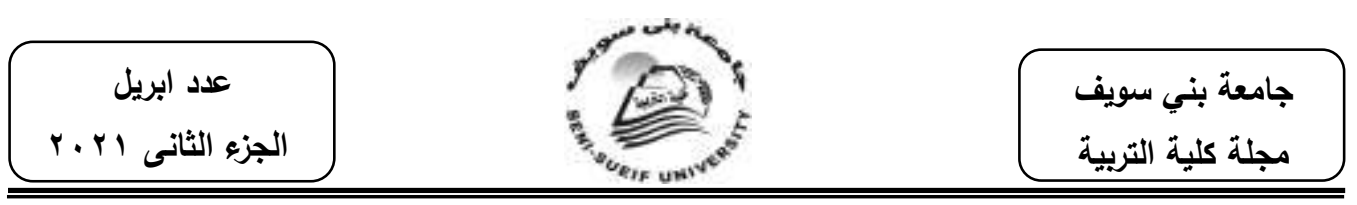

comprehension problems.

To deal with this challenge, language teachers need to employ an appropriate English teaching and learning method that should encourage students to use language with an emphasis on communicative purposes in real world settings. Project-based learning (PBL) seems to match this English teaching and learning need. Projectbased learning has been investigated in a great number of studies on the global scale over the last decade. Project-based learning is a learning method which focuses on the learner. Project-based learning is a key strategy for creating independent thinkers and learners. (Valls, 2016). It is proved that knowledge gained through learner's own effort and thinking is likely to be stored in a long-term memory. However, 'readymade' pieces of information are usually forgotten very soon. Hutchinson suggests that languages are learnt most effectively when we use them to solve problems. Problems make us think and we learn by thinking." (Hutchinson, 1999). There is a strong evidence that projects have the power to stimulate students to gather, compare, sort out and evaluate facts.

The ideology of PBL lies in "learning by doing", which means that learners acquire knowledge after having experienced or done something new (Kotti, 2008).Coufalová (2006) enforced the motto "learning by doing" and laid the four main principles that PBL (a) comes from the needs and interests of students; it enables them to fulfill their needs to gain new experiences and be responsible for their work; (b) comes from a concrete and actual situation thus it is not restricted by school premises but even parents and others from student surroundings can be involved; (C) is interdisciplinary; (d) is above all, an enterprise of a student; (e) the final product of PBL brings a concrete product and the process and result should be recorded; (f) is usually carried out in groups; (g) connects school with its neighborhood since it supports school integration into broader society and actual life.

Many studies referred that by using project-based learning, reading ability could be enhanced. Köroğlu (2011) revealed that using PBL and portfolio assessment separately, students' reading and 


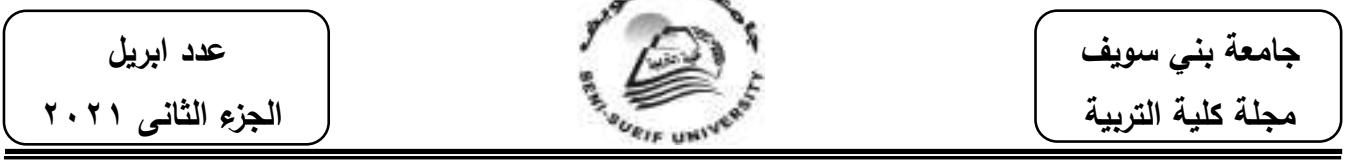

writing skills in English developed. An IT-assisted PBL lesson has multiple goals for students. Typically, these are Developing expertise, Improving research skills, Improving higher-order thinking skills, Participating in a project, Learning to use IT, conducting selfassessment and peer assessment, Developing a portfolio, Engaging in a project, Being a part of a community of scholars and working on important ideas.

\section{Context of the problem}

The researcher observed that first graders of Elsalam Secondary school have problems in acquiring the reading skills. She observed this problem through her teaching. To verify the problem, the researcher used different procedures:-

She had conducted diagnostic tests of Reading skills on first year Secondary school. The results showed that:

1 - $50 . \%$ couldn't understand the organization of a text.

2- $77 \%$ couldn't draw conclusions, summarize, compare and contrast.

The researcher found a consensus from the teachers that the majority of students faced problems in reading skills.

\section{The Problem:}

The problem is that first year secondary school students in Minia governorate had problems in their communicative reading skills. The present study tried to investigate using a program based on Project Based Learning (PBL) to solve these problems and to determine the effectiveness of this program.

\section{Questions:}

The present question attempted to provide an answer to the following question:

How effective would a program based on Project Based learning be on developing First Year Secondary School Students' Reading Skills?

\section{Hypothesis of the Research:}

The following hypotheses were tested: 
عدد ابريل

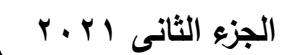

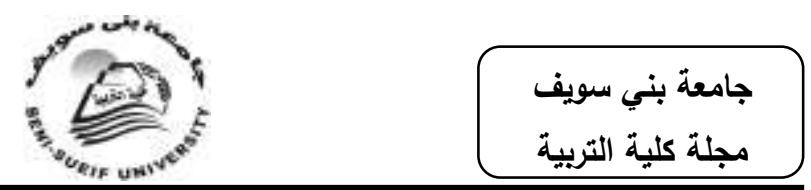

- There would be a statistically significant difference (favoring the experimental group) between means of scores obtained by the experimental and the control groups on the post-Reading test.

\section{Significance}

The present study would develop:

- Reading skills of first secondary graders of Elsalam Secondary school.

- Providing teachers with motivated and popular techniques for developing reading skills of their students.

- Helping teachers adopt new roles such as a facilitator and a guider.

\section{Delimitations}

The study was delimited to:

First year, at Elsalam secondary School students, Minia Governorate. (Participants are only females.)

Units of the first term of first year secondary school content were taught using a program based on of Project Based learning

\section{Material and methods:}

A pre-post quasi experimental design was used in the present study. The treatment and the non-treatment groups would be exposed to pre-post means of collecting data (A test in reading skills). The treatment group would be taught using a program based on Project based learning program while the non - treatment group would be taught using the conventional methods followed when teaching EFL to first secondary graders .

\section{Variables:}

- Independent variable: A program based on Project based learning.

- Dependent variable: Acquisition of Reading skills

- Control Variables:

To ensure equivalence among the members of the two groups, the following variables were controlled: a. Performance on the pre - test of Reading skills. - English proficiency level - Gender - Age

\section{Tools of the study}




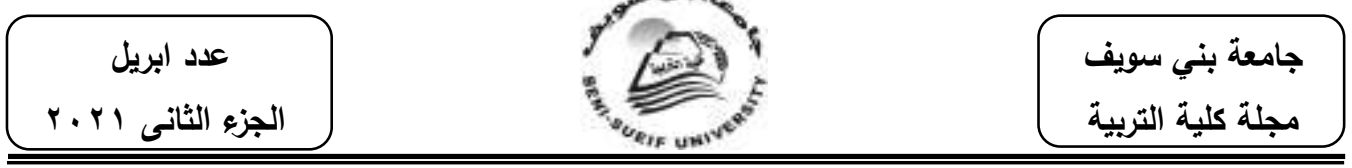

To achieve the objectives of the present study the researcher prepared the following tools:-

\section{A checklist of sub skills of Reading.}

\section{A. Objectives:}

Identifying the sub skills of Reading.

\section{B. Construction:}

The checklist consists of Reading skills that related to eight units. Consulting a number of TEFL experts to identify the sub skills of the Reading skills that appropriate for first secondary school students. Their suggestions were taken into consideration. These suggestions were reduce the number of items.

\section{A test in Reading skills}

\section{A. Objectives:}

- Predicting or guessing content because of a general understanding of the context.

- Summarizing.

- Identifying the Organization of a Text.

The Reading test consists of 3types of questions (Arrangement- Wh questions- open-ended) with 11 items based on the learning outcomes and the objectives of the program.

\section{A. Construction :}

- The test was designed on the basis of a table of specifications.

- A panel of TEFL and EFL staff members evaluated the test in the light of the table of specifications and recommended editing of some items.

- The test in its final form consisted of 11 items covering the eight units.

\section{B. Item Type:}

The test item types included the arrangement, essay and productive types (open-ended).

\section{Scoring:}

The score is simply the total number of correctly marked answers. Points given for each test item vary according response required from the participants; this is explained in the table of specifications. The 
عدد ابريل

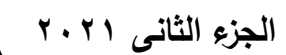

total Score of this test is (25).

E-Instructions:

Instructions of the test are written in English in an easily and simple way to avoid any ambiguity.

\section{F. Duration:}

Sixty minutes were assigned for answering the Speaking test. The researcher calculated the time between each student in the group. The average was taken.

\section{Test Validity:}

A pilot study was conducted about 15 days before administrating the program to estimate the validity and the reliability of the test.

\section{Face validity:}

The researcher distributed the test to five of a panel of TEFL and EFL experts to judge the linguistic stating of the items, suitability of the items to the participants and to the objectives. Their suggestions were taken into consideration. These suggestions were represented in the shortening of the number of items as it was too long, replacing some words in some questions, writing instructions of the test in the first page and numbering the items. The researcher arranged scores of the reading's sub-skills (30students) exponentially to determine the highest quarters (27\%) and the lowest quarters (27\%). Then t-value was computed between the two quarters. The following table shows the results:

Table (1)

t- value of the Highest and the Lowest Quarters in the Reading Test

\begin{tabular}{|c|c|c|c|c|c|c|}
\hline \multirow{2}{*}{ Variables } & \multicolumn{2}{|c|}{ Low group } & \multicolumn{2}{c|}{ High group } & \multirow{2}{*}{ t-value } & $\begin{array}{c}\text { P- } \\
\text { value }\end{array}$ \\
\cline { 2 - 5 } & Mean & SD & Mean & SD & & 0.000 \\
\hline Summarizing & 1.00 & 0.01 & 3.00 & 0.01 & $12.54 * *$ & 0.000 \\
\hline Predicting & 1.00 & 0.01 & 2.00 & 0.01 & $8.22 * *$ & 0.000 \\
\hline $\begin{array}{c}\text { Identifying Text } \\
\text { Organization }\end{array}$ & 1.88 & 0.35 & 3.50 & 0.53 & $7.17 * *$ & 0.000 \\
\hline Total & 3.88 & 0.35 & 8.50 & 0.53 & $20.41 * *$ & 0.000 \\
\hline
\end{tabular}

* Significant at 0.05

** Significant at 0.01 
The above table shows that there was a significant difference between the high group and the low group in the Reading Test (Favoring the high group). This assures the validity of the test.

\section{Test Reliability:}

The researcher used test - re-test method to calculate the reliability of the test. The researcher conducted the test on (30 students) and then reconducted it after 2 weeks. The correlation coefficient between the first implementation of the test and the second one (re-test) is shown in the following table: Table (2) reveals that the correlation coefficient of the total mark reached (0.87). This is statistically significant and proves the reliability of the test. Aiken (1994), as cited in Latif (2012), stated that the test should have a reliability coefficient ranging from $(0.70)$ and preferably closer to $(0.90)$

Table (2)

The Correlation Coefficient Between the Test and Re-Test of the Reading Test

\begin{tabular}{|c|c|c|c|c|c|c|}
\hline \multirow{2}{*}{ Variables } & \multicolumn{2}{|c|}{ Test } & \multicolumn{2}{c|}{ Re-Test } & \multirow{2}{*}{ r-value } & \multirow{2}{*}{ P-value } \\
\cline { 2 - 7 } & Mean & SD & Mean & SD & & \\
\hline Summarizing & 2.00 & 0.74 & 2.07 & 0.74 & $0.82^{* *}$ & 0.000 \\
\hline Predicting & 1.57 & 0.50 & 1.60 & 0.56 & $0.95^{* *}$ & 0.000 \\
\hline $\begin{array}{c}\text { Identifying Text } \\
\text { Organization }\end{array}$ & 2.57 & 0.77 & 2.70 & 0.84 & $0.91^{* *}$ & 0.000 \\
\hline Total & 6.13 & 1.22 & 6.37 & 1.25 & $0.87^{* *}$ & 0.000 \\
\hline
\end{tabular}

** Correlation is significant at the 0.01 level (2-tailed).

\section{Item Analysis:}

The researcher conducted the Reading Test to identify the suitability of the test to the students. Thirty first year secondary school students were chosen randomly to answer the test. Item analysis was done after scoring the test to identify suitability of the items to the students and to provide information concerning the following points:

1 - Index of difficulty.

2- Index of discrimination . 


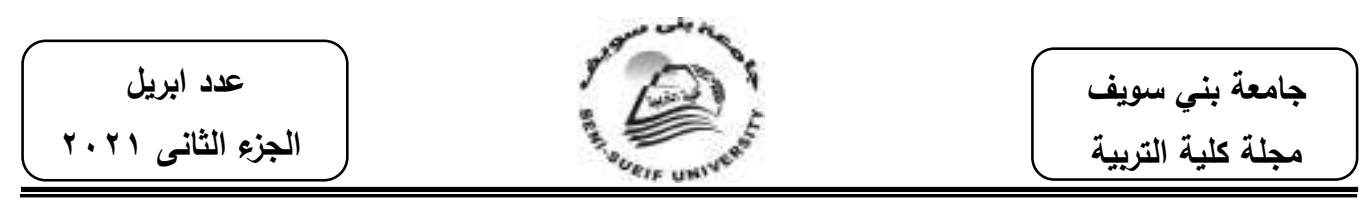

Table (3)

Difficulty Index and Discrimination Power of the Reading Test of the Pilot Study

\begin{tabular}{|c|c|c|c|}
\hline Number of Question & 1 & 2 & 3 \\
\hline Simplicity index & 0.31 & 0.33 & 0.34 \\
\hline Difficulty index & 0.69 & 0.67 & 0.66 \\
\hline Discrimination Power & 0.21 & 0.22 & 0.22 \\
\hline
\end{tabular}

Table ( 3 ) shows that :

1- Difficulty indices ranged from (0.66) to (0.69). These percentages show that the Reading Test includes various questions that involve easy and difficult questions to suit the different levels of the participants.

2- The Reading test had a positive discriminating power: The discrimination indices ranged from $(0.21)$ to $(0.22)$.

\section{Findings: Hypothesis 1}

Hypothesis (1) predicted that the treatment group would surpass the non - treatment group at the (.01) level on the post test of reading skills. Table (4) shows the data obtained to verify this hypothesis.

\section{Table (4)}

t-Test Results of the experimental and the control groups on the post testing of Reading

\begin{tabular}{|c|c|c|c|c|c|c|}
\hline \multirow{2}{*}{ Variables } & \multicolumn{2}{|c|}{ Experimental } & \multicolumn{2}{|c|}{ control } & \multirow{2}{*}{ t-value } & \multirow{2}{*}{ P-value } \\
\cline { 2 - 5 } & Mean & SD & Mean & SD & \\
\hline $\begin{array}{c}\text { Summarizi } \\
\text { ng }\end{array}$ & 5.58 & 0.90 & 3.27 & 0.49 & $12.39^{* *}$ & 0.000 \\
\hline Predicting & 4.75 & 0.87 & 3.42 & 0.72 & $6.47^{* *}$ & 0.000 \\
\hline $\begin{array}{c}\text { Identifying } \\
\text { Text } \\
\text { Organizati } \\
\text { on }\end{array}$ & 9.38 & 1.16 & 4.65 & 0.56 & $20.17^{* *}$ & 0.000 \\
\hline Total & 19.72 & 1.66 & 11.33 & 0.95 & $23.96^{* *}$ & 0.000 \\
\hline
\end{tabular}

* Significant at 0.05

** Significant at 0.01 


\begin{tabular}{|c|c|c|}
\hline 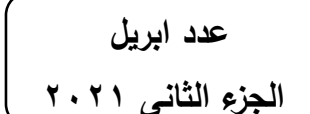 & 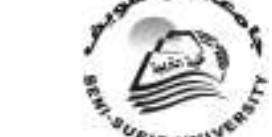 & جامعة بني سويفة \\
\hline
\end{tabular}

Based on the data in the above table, the t-value (23.96) obtained is significant at the (0.01) level. Thus, hypothesis (1) is accepted.

\section{Discussion}

The present study set out to determine the effect of a program based on Project Based Learning program (PBLP) integrated with Information Technology (PBLP\&IT) on the acquisition of reading skills. The results showed that students learned reading easily through this program. Table (4) shows that the treatment group outperformed the non-treatment group. Results revealed in table (4) confirmed hypothesis 1. Participants of the treatment group (who were taught by the program) surpassed their counterparts in the non - treatment group (who were taught by the conventional methods), in reading test.

The present study cops up with the results of Köroğlu (2011) that using PBL and portfolio assessment separately, students' reading and writing skills in English developed. The following results shows a significant effect of PBL on participants' reading post-test. The following table shows the experimental Reading of post \& pre Test.

\section{Table(5)}

\section{The experimental Reading of post \& pre Test}

\begin{tabular}{|c|c|c|c|c|c|c|c|}
\hline \multirow{2}{*}{ Variables } & \multicolumn{2}{|c|}{ Pre Testing } & \multicolumn{2}{c|}{ Post Testing } & \multirow{2}{*}{ t-value } & \multirow{2}{*}{ P-value } & $\boldsymbol{\eta} 2$ \\
\cline { 2 - 5 } & Mean & SD & Mean & SD & & \\
\hline Summarizing & 1.85 & 0.68 & 5.58 & 0.90 & $21.25^{* *}$ & 0.000 & 0.94 \\
\hline Predicting & 2.23 & 0.41 & 4.75 & 0.87 & $13.85^{* *}$ & 0.000 & 0.87 \\
\hline $\begin{array}{c}\text { Identifying } \\
\text { Text } \\
\text { Organization }\end{array}$ & 3.00 & 1.16 & 9.38 & 1.16 & $26.03^{* *}$ & 0.000 & 0.96 \\
\hline Total & 7.08 & 1.60 & 19.72 & 1.66 & $51.20^{* *}$ & 0.000 & 0.99 \\
\hline
\end{tabular}

* Significant at 0.05

The above table ( 5 )shows that the $\mathrm{t}$ - value ranged from (13.85) to (51.20). This refers to the effect of the Project Based Learning Program (PBLP) in developing first secondary school students' reading. 


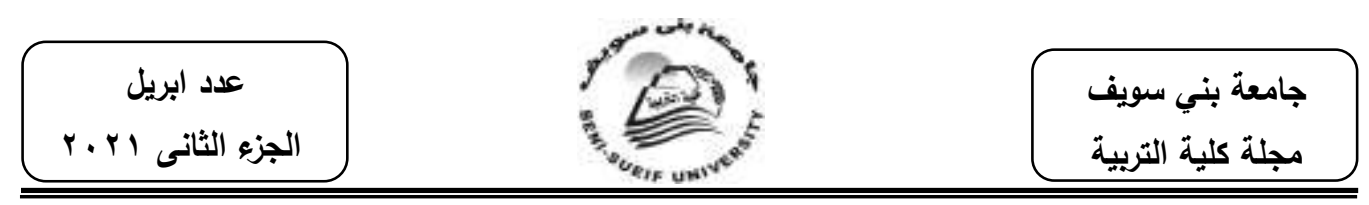

The findings of the present study coincide with the literature reviewed. The results coincide with the results of those studies investigating the effects of using (PBLP) on developing reading skills. There is a consensus between the results of the present study and those of other studies investigating the positive effects of (PBLP) on reading skills:

The researcher noted that the program of project based learning integrated with information technology motivated students to use language and participate. Rayan and Deci (2000) stated that where there is motivation, it leads to productivity. Using the program of the present study had a positive effect on increasing motivation of students of the treatment group. It leads to the development of acquiring reading skills. It was further noted that confidence increased among pupils of the treatment group. They were provided with skills that enabled them to depend on themselves in producing language.

\section{Conclusion}

The discussion above demonstrated that using the PBLP could be effective in developing reading skills. Suggestions for further research:

- A replication of the present study to be implemented on a wide number of students and different grades.

- The effect of a Project Based Learning Program on developing receptive language skills.

- The effect of a Project Based Learning Program on developing independent learning at the secondary stage.

- The effect of Project Based Learning Program on reducing anxiety and increasing confidence.

- Investigating the effect of using Project Based Learning Program on developing students' communication skills. 


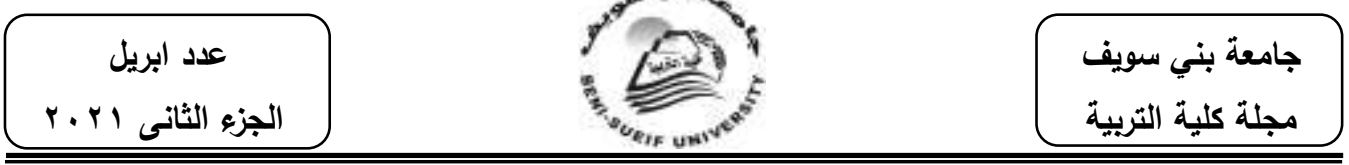

\section{References:}

Block, C. \& Israel, S. (2005). Reading first and beyond: The complete guide for teachers and literacy coaches. Thousand Oaks, CA: Corwin Press.

Coufalová, J. (2006). Projektovévyučování. Praha: Nakladatelství Fortuna.

Hellyer, R., Robinson, C., \& Sherwood, P. (2001). Study skills for learning power (2nd ed.). Boston: Houghton Mifflin Company.

Kalayci, S. (2012). "A Journey to Bilingualism" A Case Study of GermanTurkish Bilingual

Family. Educational Process: International Journal, 1(1-2), 29-38.

Hutchinson, T. (1996). Hotline: Intermediate. Workbook. Oxford:

Oxford University Press.

Kalayci, S. (2012). "A Journey to Bilingualism” A Case Study of

German-Turkish Bilingual Family. Educational Process:

International Journal, 1(1-2), 29-38.

Kazerooni. S. (2013). The effects of exposure to literary texts on reading comprehension and vocabulary retention: Literature - Majors VS. Translation - Majors. AJTLHE, 5(1), 12-33.

Köroğlu, M. (2011). The effects of project based and portfolio based learning on high school students' reading and writing skills in English. Master thesis. Uludağ University, Bursa.

Kotti, D. (2008). Experiential learning from theory to practice. Adult Education, 13,35-41.. (in Greek)

Onchera, P. (2013). Functional Writing Skills for Effective

Communication The English Language Classroom in Kenya.

Journal of Emerging Trends in Educational Research and Policy Studies

Ryan, R. \& Deci, E. (2000). "Self-Determination Theory and the

Facilitation of Intrinsic Motivation, Social Development, and Well-

Being” The American Psychological Association, Inc Vol.55; No.

1; Pp. 68-78.

Valls, B. (2016). "Analysis of Project Based Learning in a Digital

Environment at a Networked High School," J. Educ.Teach.

Trainers, vol. 7, no. 1, 27-49, 2016. 